\title{
Vertical Communication and Employee Performance in Emerging Economy Public Organizations: The Imperatives of Organizational Culture
}

\author{
Korsi Doonu Gbarale, Sorbarikor Lebura \\ Department of Management, Rivers State University, Port Harcourt, Nigeria \\ Email address: \\ sorbarikor.lebura@ust.edu.ng (S. Lebura) \\ To cite this article: \\ Korsi Doonu Gbarale, Sorbarikor Lebura. Vertical Communication and Employee Performance in Emerging Economy Public Organizations: \\ The Imperatives of Organizational Culture. European Business \& Management. Vol. 6, No. 6, 2020, pp. 171-177. \\ doi: $10.11648 /$ j.ebm.20200606.16
}

Received: November 18, 2020; Accepted: December 23, 2020; Published: December 31, 2020

\begin{abstract}
The focus of this paper was to investigate the relationship between vertical communication and employee performance within emerging economy public organizations. Previous studies on organizational communication and employee performance have mostly been undertaken within the context of the private sector, with very few studies focused on the public sector. Hence, the focus of this paper on the exploration of how vertical communication impacts on employee performance, especially considering the moderating role of organizational culture on this relationship. The study adopted the cross-sectional survey as the design for the study and utilized the questionnaire as the primary data collection tool. A total of 461 participants were involved in the study as sourced from the Rivers State Civil Service Commission. Three hypotheses were tested, assessing the relationship between vertical communication and two stated measures of employee performance, namely employee effectiveness and efficiency (bivariate); and also, that which assessed the moderating role of organizational culture on the relationship between vertical communication and employee performance. The findings showed that vertical communication significantly contributes towards employee performance as evidenced by outcomes such as employee effectiveness and efficiency. There is also evidence that organizational culture significantly moderates the relationship between vertical communication and employee performance. In conclusion, this study affirms that the vertical flow of communication across the organization drives the performance of employees, though this is highly dependent on the culture of the organization.
\end{abstract}

Keywords: Employee Performance, Effectiveness, Efficiency, Organizational Culture, Vertical Communication

\section{Introduction}

It is common knowledge that organizations require their employees or workers to behave in a certain way as well as perform better at all times, if the organization is to survive and achieve their set aims. The various forms of behavior and attitudinal disposition which organizations require of their employees in order to actualize set goals depend on the kind of communication system existing in the organization. Over time it has been observed that organizations continue to lay emphasis on ensuring that employees are performing at their very best, as these employees are key to organizational survival [26].

Scholars have indicated that internal communication has the sole aim of establishing and maintaining a mutually beneficial relationship within the firm that leads to increased organizational performance [35]. This relationship is very important because employees would execute tasks based on their identification with management as well as the set goals and objectives of the organization [24].

Attention has been given to the study of organizational communication in organizational behaviour research as a result of the significance of this variable to organizational outcomes. It has been found that organizational communication aids the improvement of employee job performance [21]. Both vertical and horizontal communication are deemed as being instrumental to the success of most business organizations [36]. Specifically, vertical communication impacts organizational success by improving job satisfaction and employee commitment to the 
organization [17, 22, 27].

It had earlier been pointed out that research is lacking in studies examining employee performance as a consequence of vertical communication within the context of public sector organizations within developing contexts [2]. This study addresses this gap as it investigates the relationship between vertical communication and employee performance in the Rivers State Civil Service. This presents a shift from the noted focus on private sector organizations and advances a more insightful approach towards understanding the implications of communication forms on public sector employees [1].

\subsection{Research Questions}

The following research questions are posed to address the set purpose and provide answers to this study:

i. To what extent does vertical communication relate with employee effectiveness in Rivers State Civil Service Commission?

ii. To what extent does vertical communication relate with employee efficiency in Rivers State Civil Service Commission?

iii. To what extent does organizational culture moderate the relationship between vertical communication and employee performance in Rivers State Civil Service Commission?

\subsection{Hypotheses for the Study}

To provide answers to our research questions stated above the following hypotheses are stated:

$\mathrm{Ho}_{1}$ : There is no significant relationship between vertical communication and employee effectiveness in Rivers State Civil Service Commission.

$\mathrm{H}_{02}$ : There is no significant relationship between vertical communication and employee efficiency in Rivers State Civil Service Commission.

$\mathrm{H}_{03}$ : Organization culture does not significantly moderate the relationship between vertical communication and employee performance in Rivers State Civil Service Commission.

\section{Literature Review}

\subsection{Vertical Communication}

Organizational communication can be defined considering different aspects such as the positions of the sender and recipient in the organization's hierarchy, the abstraction level, what the communication aims to achieve, its content, the direction of the communication, etc. [4]. This paper explores organizational communication from the perspective of the direction of the communication, which could be either horizontal or vertical, with a focus on vertical communication.

Vertical communication is defined as work-related communication that moves from the top down or down to the top within the organization's hierarchy $[10,14]$. This means that vertical communication is communication within the workplace that moves either upwards or downwards, touching on issues related to the tasks of workers that lead to the achievement of organizational goals and objectives. In other words, it is hierarchical communication, from the heads of the highest hierarchical level to the managers at the lowest level through direct contact, and then to the lowest levels of the hierarchical pyramid structure to the executors.

It is mostly utilized in giving orders, tasks assignment, feedback provision and other necessary workplace related practices and processes aimed at improvement of work relationships $[15,31]$. These relationships are hugely influenced by the communication emanating from top management of the firm, as the perception of working conditions by employees to be satisfactory could be based on their understanding of work expectations [9]. In other words, when employees deem their work expectations to be clear enough as a result of adequate communication form management, then they are more likely to regard their working conditions to be satisfactory. This indicates that a lack of work clarity from higher hierarchical structures, specifically in terms of the different task expectations could result to workplace stress among employees [25]. Vertical communication can reduce such uncertainty about the firm's position thereby ensuring that workers are aware of its make-up and outlook [30]. This means acquainting employees with the firm's mission, goals, achievements and other key characteristics, thereby leaving no room for ambiguity and confusion of the workers about the firm [5, 33]. Hence, organizations utilize vertical communication to properly and adequately update their employees on those unique features that differentiate them from others in the same industry or environment [29].

Aside from passing down information to employees, vertical communication can also be in the form of the CEO mingling with the employees and getting feedback directly, which further makes the employees have more sense of satisfaction and belonging. Such communication flow inspires employee involvement and participation in policy formulation as well as ownership of such formulated policies [13]. This presents management with a chance to elicit information about organizational operations and activities from the lowermost level of the organization, which in the long run expectedly improves job satisfaction. Vertical communication may also convey employee concerns, problems and exclusions to repetitive work in terms of the work-related difficulties being encountered to management. In this regard, it mainly entails suggestions and recommendations for improving task-related processes, periodic reports on departmental as well as individual performances and diverse work complaints, that serve as feedback to management, aimed at improving the system [3].

\subsection{Employee Performance}

The success of every organization is tied to how well such an organization performs in the discharge of its duties. This has led managers of both public and private organizations to always galvanize the workforce towards the improvement of organizational performance, which was defined as "the accumulated results of all the organization's work activities" [31]. It is also regarded as an outcome that occurs as a function 
of individuals' behaviours in an organization [34]. These different individuals are the employees that make up the organization, who must always ensure that they put in sufficient efforts individually which when collectively managed leads to the achievement of the set organizational goals and objectives. Two ways to measure employee performance is to assess how efficient and effective such employees have been at carrying out their tasks.

Effectiveness has been generally regarded as doing the right things within the workplace. It is also defined as the extent to which an organization achieves a goal that it has set for itself or "a measure of how well an activity contributes to achieving organizational goals" [7, 8]. This is a key approach to measuring how much contribution the employee makes in the drive to achieve set organizational goals and objectives, hence it is used by managers to assess the usefulness of employees. It is expected that employees do exactly what they have been asked to do by their superiors, as that is a key performance index used by managers during appraisals of employees reporting to them.

Efficiency is generally seen as doing things right, even as it is defined as a measure of the inputs needed for every unit of product or service output [7]. It is also "the use of minimal resources- raw materials, money and people - to produce a desired volume of output" [8]. These definitions indicate that in deciding how efficient an individual has been in the discharge of his or her duties, it is important to note what quantity of resources have been utilized to achieve certain outputs. In other words, if an employee spends 30 minutes to produce 10 items while another employee spends an hour to produce same number of items the first employee is deemed to be more efficient with the resources and the production of the items that were expected by the management.

Form the above definitions, it can be seen that the performance of employees which can be measured either in terms of efficiency or effectiveness has a huge impact on organizational performance thereby leading to the achievement of firm success. Hence, these measures must be taken seriously especially when it has to do with public organizations in Africa.

\subsection{Organizational Culture as a Moderating Variable}

Every organization is made up of a system which is mainly run by the different environments of the organization, one of which is the cultural environment [20]. This makes it expedient that the paper explores the moderating role of organizational culture on the relationship between vertical communication and performance within the public sector workplace.

Organizational culture refers to a set of distinct value system which enables an organization to effectively coordinate it activities and the internal relations of its members. Organizational culture provides workers the blueprint with which to understand the functioning of the organizations by sharing in its norms, values and rules and regulations [2]. Organizational culture has remarkable effect on the workers' perceptions and regard for organizational membership as well as continuity within the organization [1]. If the employees of the organization have more understanding of the organizational culture, they will have more job satisfaction [12].

The culture of the organization is described as a setup of behavior, attitude and values [28]. Organizational culture and workers retention have a strong and significant relationship, however, organizations with negative organizational culture are constantly faced with the tendency of employees quitting for better offers elsewhere [12]. This is as organizational culture has been observed to significantly impact on the workers desire and willingness to remain with the organization. If the culture is positive then the employees are more likely to remain with the organization. If the organizational culture is negative then it would cause high rate of turnover. If the organization looks after her employees then the employees will definitely look after the organization. In order to remedy the employee turnover problem there is a need for the organization to recognize that indeed they have turnover problem [2]. Effective management entails identifying issues within the workplace and the development of appropriate strategies to tackle or handle such issues [1].

\subsection{Vertical Communication and Employee Performance}

Various studies in recent times have emphasized the importance of vertical communication to the success of organizations $[17,22,36]$. A related research had earlier noted that there are overwhelming benefits associated with managers clearly signposting the reasons informing the actions taken and expected in communicating to their subordinates [32]. In most cases, management within an organization ignores these aspects when communicating, with the focus mostly being on the dissemination of such information to employees. It is even argued that while it may be tedious and time-consuming to communicate the rationale behind the instructions being passed to employees, the latter's confidence, trust in the system and support for such decisions are strengthened by such explanations [11].

On the other hand, the participative nature of the contemporary employee means that they want to be actively involved in the decision-making process, rather than just being a passive recipient of information passed from top management. This has become a major source of concern to top and middle management in recent times. It is noted that while organizations can utilize downward style of vertical communication, the upward style of communication is also very important as it provides an opportunity for employees to express their views and give feedback to management [32]. The importance of upward communication is summed up as helping employees to assuage the apprehensions and challenges associated with their specific job descriptions, while supporting management with the requisite information to make informed decisions [37]. Furthermore, it aids the facilitation of employee participation and involvement which raises employee consciousness, thereby serving as measure of effective downward communication. This takes place as the employees provide feedback to reflect how effective the 
downward communication they have received has been.

\section{Methodology}

The study is a survey research design as it investigated the characteristics and relationship between social constructs within non-contextual settings. The target population of this study consisted of 235 employees in the Rivers State Civil Service. The sample size was obtained using the Taro Yamene's formula, leading to sample size of 149. A self-administered questionnaire with three sections A, B \& C was prepared and used to generate data from the managers, supervisors and others in the target parastatals. The instrumentation for the variables was based on previous empirical research and adapted in line with that of the current study - the instrument for vertical communication, employee performance (effectiveness and efficiency) and organizational culture were based on earlier studies $[1,6,16]$.

\section{Research Findings}

A total of 149 copies of the questionnaire were distributed and 146 copies successfully retrieved. The results are illustrated in this section using contingency tables. A total of 3 null hypotheses are tested with results presented accordingly. The bivariate hypotheses addressed the assumed relationship between vertical communication and the measures of employee performance, while the multivariate hypothesis addressed the moderating impact of organizational culture on the relationship between the variables.

$\mathrm{Ho}_{1}$ : There is no significant relationship between vertical communication and employee effectiveness in the Rivers State Civil Service Commission.

Table 1. Correlations Analysis showing the Relationship between Vertical Communication and Employee Effectiveness.

\begin{tabular}{|c|c|c|c|c|}
\hline Type & Variables & Statistics & Vertical communication & Employee effectiveness \\
\hline \multirow{5}{*}{$\begin{array}{l}\text { Spearman's } \\
\text { rho }\end{array}$} & \multirow[t]{2}{*}{ Vertical communication } & Correlation Coefficient Sig. (2-tailed) & 1.000 & .330 \\
\hline & & $\mathrm{N}$ & - & .008 \\
\hline & \multirow{3}{*}{ Employee Effectiveness } & Correlation Coefficient & .008 & 1.00 \\
\hline & & Sif. (2-tailed) & 146 & - \\
\hline & & $\mathrm{N}$ & & 146 \\
\hline
\end{tabular}

Table 1 shows the Spearman's correlation coefficient (rho) $=0.330$. This value is substantial thereby showing that there is a significant relationship between vertical communication and employee effectiveness. The positive sign of the correlation coefficient means that a positive significant relationship between the variables study. Thus, the null hypothesis is rejected on the basis of the evidence of a significant relationship between the variables.

$\mathrm{HO}_{2}$ : There is no significant relationship between Vertical Communication and employee efficiency in the Rivers State Civil Service Commission

Table 2. Correlations Analysis showing the Relationship between Vertical Communication and Employee Efficiency.

\begin{tabular}{|c|c|c|c|c|}
\hline Type & Variables & Statistics & Vertical communication & Employee efficiency \\
\hline \multirow{5}{*}{ Spearman's rho } & \multirow{3}{*}{ Vertical communication } & Correlation Coefficient & 1.000 & .401 \\
\hline & & Sig. (2-tailed) & & .000 \\
\hline & & $\mathrm{N}$ & 146 & .146 \\
\hline & \multirow[b]{2}{*}{ Employee efficiency } & Correlation Coefficient & .401 & 1.000 \\
\hline & & Sig. (2-tailed) & .000 & - \\
\hline
\end{tabular}

Table 2 shows the Spearman's correlation coefficient $($ rho $)=0.401$, this value showed a substantial relationship between vertical communication and employee efficiency. The positive sign of the correlation coefficient means that there is a positive and significant relationship between vertical communication and employee efficiency. This implies that an improvement in in vertical communication is associated with increased employee efficiency in the Rivers State Civil Service Commission. Thus, on the basis of the evidence, the null hypothesis is rejected

$\mathrm{H}_{03}$ : Organizational culture does not significantly moderate the relationship between effective communication and employee performance in the Rivers State Civil Service

\section{Commission.}

The third hypothesis is observed to be significant at an indirect relationship with rho of 0.725 and a p-value at 0.00 which is $\mathrm{p}<0.05$; the values indicate significant moderating effect of organizational culture on the relationship between vertical communication and employee performance in the Rivers State Civil Service Commission. Based on this finding, we therefore reject the null hypothesis of no significant moderating effect and restate that organizational culture significantly moderates the relationship between vertical communication and employee performance in the Rivers State Civil Service Commission. 
Table 3. Partial Correlations Analysis showing the Moderating effect of Organizational Culture on the Relationship between Effective Communication and Employee Performance.

\begin{tabular}{|c|c|c|c|c|c|}
\hline Control variables & & & Vertical communication & Employee performance & Culture \\
\hline \multirow{12}{*}{- non- $^{\mathrm{a}}$} & \multirow{3}{*}{$\begin{array}{l}\text { Vertical } \\
\text { communication }\end{array}$} & Correlation & 1.000 & 725 & .722 \\
\hline & & Significance (2-tailed) & - & .000 & .000 \\
\hline & & Dr & 0 & 142 & 142 \\
\hline & & Correlation & 725 & 1.000 & 966 \\
\hline & Employee & Significance (2-tailed) & .000 & - & .000 \\
\hline & \multirow[t]{2}{*}{ Performance } & $\mathrm{Df}$ & 142 & 0 & 142 \\
\hline & & Correlation & .722 & 966 & 1.000 \\
\hline & \multirow{2}{*}{ Culture } & Significance (2-tailed) & .000 & .000 & - \\
\hline & & Df & 142 & 142 & 0 \\
\hline & \multirow{3}{*}{$\begin{array}{l}\text { Vertical } \\
\text { communication }\end{array}$} & Correlation & 1.000 & 521 & .722 \\
\hline & & Significance (2-tailed) & - & .000 & .000 \\
\hline & & Df & 0 & 141 & 141 \\
\hline \multirow{3}{*}{ Culture } & \multirow{3}{*}{$\begin{array}{l}\text { Employee } \\
\text { Performance }\end{array}$} & Correlation & .521 & 1.000 & \\
\hline & & Significance (2-tailed) & .000 & - & \\
\hline & & Df & 141 & 0 & \\
\hline
\end{tabular}

\section{Discussion of Findings}

The finding of the study revealed that there is a significant relationship between vertical communication and employee performance. The positive sign of the correlation coefficient means that there is a positive significant relationship between vertical communication and the two measures of employee performance. Therefore, it showed that improvement in vertical communication in terms of downward and upward communication as well as the involvement of workers in decision making is associated with an improvement employee performance in the Rivers State Civil Service Commission. This could be attributed to the understanding that workers derive from the vertical communication which takes place between them and management, while they are also free to give feedback to management on issues that arise within the organization.

The result of this study corroborates the conclusion of a study which investigated the effects of communication strategies on organizational performance and reached a conclusion that effective organizational performance is dependent on how open the organization's communication environment is [18]. In other words, once organizational members feel free to share feedback, ideas and even criticism at every level, it increases performance. Another study asserted that the importance of downward communication cannot be overemphasized, noting that clarity of decision rationale can only be to the benefit of the organization, no matter how stressful and costly it may seem [32].

The findings of this study revealed a significant and positive influence of organizational culture of Rivers State Civil Service Commission as a moderating variable on the relationship between vertical communication and employee performance. The study further corroborates the conclusion that employee job performance is significantly influenced by the culture of the organization which further leads to improved productivity [6]. This influence by the culture of the organization in the long run leads to improved performance.
It further validates the conclusions reached earlier that organizational culture directly impacts on other key performance outcomes of any organization, including customer satisfaction and business growth [19]. Also, the robust effects of organizational culture are consistent across a diverse range of businesses as well as sectors or industries, such as retail, religious organizations, educational institutions, hospitality, construction and manufacturing.

\section{Conclusion}

This study was carried out to investigate the relationship between vertical communication and employee performance within public organizations, with a focus on the Rivers State Civil Service Commission. The findings revealed that vertical communication has a significant relationship with the performance of workers within the Rivers State Civil Service Commission, while organizational culture positively moderates the relationship between both variables. These results are consistent with the literature stating that the general functions and features of communication flow in different directions. In other words, the features of effective communication, particularly vertical communication content plays an important role in enhancing workers effectiveness and efficiency.

Therefore, vertical communication in the Rivers State Civil Service Commission serves for transmitting policies and regulations, for reducing information ambiguity, as well as for creating and maintaining social relationships among organizational members, which then contributes to enhancing employees' performance. Based on the findings from this study, it is concluded that vertical communication has a significant impact on employee performance and should be deployed more often by top and middle management of public sector organizations within the emerging economies as this will lead to empowering the employees thereby resulting in improved service delivery by such organizations. It is noteworthy to point that there should be a mixture of both downward and upward styles of vertical communication in order to reap the full benefits of this dimension of 
organizational communication.

\section{References}

[1] Adeniji, A. A. \& Osibanjo, A. O. (2012). Human resource management: theory and practice. Pumark: Nigeria Limited.

[2] Anankwe, U. P. (2002). Human Resource Management Practices in Nigeria: Challenges and Insights. International journal of human resource management, 3 (7), 1042-1059.

[3] Barney, J. B. (2002). Gaining and Sustaining Competitive Advantage, 2nd edition. Upper Saddle River: New Jersey Pearson Education.

[4] Bartels, J., Peters, O., de Jong, M., Pruyn, A. \& van der Molen, M. (2010). Horizontal and vertical communication as determinants of professional and organizational identification, Personnel Review, 39 (2), 210-226.

[5] Bednar, J. S., Galvin, B. M., Ashforth, B. E., \& Hafermalz, E. (2020). Putting identification in motion: A dynamic view of organizational identification. Organization Science, 31 (1), 200-222.

[6] Bellou, V. (2010). Organizational culture as a predictor of job satisfaction: The role of gender and age. Career development international, 15 (3): 4-19.

[7] Boddy, D. (2008). Management: An introduction, $4^{\text {th }}$ edition. Essex, England: Prentice Hall.

[8] Daft, R. L. (2003). Management, $6^{\text {th }}$ edition. Ohio: Thomson.

[9] Dess, G. G. \& Shaw, J. D. (2006). Voluntary turnover, social capital and organizational performance. Academy of management review, 26 (3), 446-456.

[10] Downs, C. W. \& Adrian, A. D. (2004). Assessing Organizational Communication: Strategic Communication Audits. New York: The Guilford Press.

[11] Etzioni, A. (2014). Humble Decision-Making Theory. Public management review, 16 (5), 611-619.

[12] Fajana, S. (2002). Human Resources Management: An introductory. Lagos: Labofin and Company.

[13] Giri, V. N., \& Kumar, B. P. (2010). Assessing the impact of organizational communication on job satisfaction and job performance. Psychological studies, 55 (2), 137-143.

[14] Goldhaber, G. M. (1993). Organizational Communication, 6th ed. New York: McGraw-Hill.

[15] Greenberg, J. \& Baron, R. A. (2008). Behavior in organizations, 9th edition. Upper Saddle River, NJ: Pearson Education.

[16] Husain, Z. (2013). Effective Communication Brings Successful Organizational. The business \& management review, 3 (2), 43-50.

[17] Jung, S. J. \& Park, J. (2017). The Effects of Educational Training and Organizational Communication on Job Performance in General Hospitals. The Korean Journal of Health Service Management, 11 (4), 17-28.

[18] Kibe, C. W. (2014). Effects of Communication Strategies on Organizational Performance: A Case Study of Kenya Ports
Authority. European journal of business and management, 60 (1), 6-10.

[19] Lee, S. (2013). Determinants of federal employees' turnover across agencies: Paper presented at the 11 Public management research conference, Madison, Wisconsin, June 20-22.

[20] Lehman, C. M. \& DuFrene, D. D. (2015). Managing virtual teams. Business Expert Press.

[21] Markiz, Y., Margono, S., Wirawan, I. D. \& Ainur, R. (2017). The influences of leadership styles, organizational communication, and job satisfaction toward employees' job performance in doing construction jobs: a study on three construction companies in Jakarta. Russian Journal of Agricultural and Socio-Economic Sciences, 65 (5), 168-180.

[22] Mehra, P. \& Nickerson, C. (2019). Organizational communication and job satisfaction: what role do generational differences play?. International Journal of Organizational Analysis, 27 (3), 524-547.

[23] Melvile. S \& Goddard, W. (2004). Research Methodology: An introduction. Kenwyn: Juta \& Co Ltd.

[24] Miller, K. (2006). Organizational Communication: Approaches and Processes. Belmont, CA: Thomson/ Wadsworth.

[25] Naeem, K., Dapeng, L., Durrani, D. K. \& Anjum, M. A. (2019). High-performance work practices versus work-role ambiguity. Human Systems Management, 38 (2), 141-148.

[26] Nagi, D., \& Mohammed Ali, Y. (2020). The Effect of Talent Management Practices on Employee Performance. International Journal of Management, 11 (9).

[27] Ogundipe, C. F., Adetayo, H. O., Bankole, O. A., \& Akinbowale, F. O. (2020). Communication: A Modern Dimension of Job Involvement and Employee Commitment: A Case Study of Public Health Workers in Ekiti State. International Journal of Innovative Science and Research Technology, 5 (2), 91-97.

[28] Onuka, A. O. U. (2006). Management manpower development in the Context of globalization: An evaluation. In International Journal of African African American Studies, 1, 17-28.

[29] Postmes, T. (2003). A social identity approach to communication in organizations. In Haslam, S. A., Van Knippenberg, D., Platow, M. J. \& Ellemers, N. (Eds.) Social identity at work - developing theory for organizational practice (pp. 81-98). New York: Psychology Press.

[30] Postmes, T., Tanis, M. \& De Wit, B. (2001). Communication and commitment in organizations: a social identity approach, Group Processes and Intergroup Relations, 4 (3), 227-246.

[31] Robbins, S. P. \& Coulter, M. (2013). Management, $11^{\text {th }}$ edition. Essex: Pearson.

[32] Robbins, S. P., T. A. Judge, \& T. T. Campbell. (2010). Organizational Behaviour. Essex, England: Pearson Education Limited.

[33] Su, L., \& Swanson, S. R. (2019). Perceived corporate social responsibility's impact on the well-being and supportive green behaviors of hotel employees: The mediating role of the employee-corporate relationship. Tourism Management, 72, 437-450. 
[34] Szilagyi, M. \& Wallace, 0. (1999). Organizational Behaviour and Management. New York: Harper and Row.

[35] Tench, R., \& Yeomans, L. (2017). Exploring public relations: global strategic communication. Pearson Higher Ed.

[36] Terzic, E. (2018). The significance of vertical and horizontal communication for business effectiveness in sports organizations. International Scientific Journal of Kinesiology, 110-118.

[37] Tubbs, S. \& Moss, S (2008). Human Communication: Principles and Contexts. Boston, MA: McGraw-Hill. 